BIOMEDICAL AND BIOSOCIAL ANTHROPOLOGY
$\begin{gathered}\text { Official Journal of the International Academy } \\ \text { of Integrative Anthropology } \\ \text { journal homepage: http://bba-journal.com }\end{gathered}$

\title{
Forecasting early climax on taking into account of reproductive and biological age indicators
}

Efimenko O.O., Retunska I.M., Marturosova T.O.

State institution institute of pediatrics obstetrics and gynecology named after academic O.M. Lukyanova National Academy of Medical Sciences of Ukraine, Kyiv, Ukraine

\section{ARTICLE INFO}

Received: 21 March 2019

Accepted: 19 April 2019

UDC: $618.173-039.11-053.7 / .84$

\section{CORRESPONDING AUTHOR}

e-mail: iryna.shakalo@gmail.com Retunska I.M.

\begin{abstract}
A great asset of our time is a significant increase in life expectancy. This is especially true for women's health issues, as women live longer than men and are more stubbornly opposed to age-related changes and aging, trying to preserve not only beauty and youth, but also reproductive function. The use of algorithms and mathematical models for predicting the occurrence of pathology in medical practice makes it possible to predict in advance not only the fact of the occurrence of this complication, but also to determine the likelihood of its occurrence, which is very important for the subsequent identification of risk groups in order to develop individualized preventive and treatment measures. Namely, the timely appointment of preventive measures and the development of individual treatment programs will improve the quality of life of every woman. The purpose of the work is to develop an algorithm and a mathematical model for predicting the risk of developing early climax (EC) against the background of a woman's biological aging by studying various factors with the subsequent development of individualized preventive and treatment measures. In order to study the possibilities of predicting the occurrence of RK against the background of a woman's biological aging, a retrospective analysis of the frequency of the studied factors in patients with EC was carried out in comparison with women with preserved menstrual function and timely onset of menopause. The method of step-by-step discriminant analysis was used as a mathematical model, which made it possible to identify the probability of a difference between the comparison groups by the $F$ value of Fisher statistics, to develop a forecast algorithm and conduct mathematical modeling. 12 out of 145 factors were identified by discriminant analysis, which most influenced the occurrence of this pathology, including the following: early menopause in relatives, smoking, history of artificial abortion (more than 3), extragenital pathology; the presence of stressful situations at home, at work; surgery on the uterus and appendages; inadequate physical and mental activity; adiposity; low serum estradiol concentrations; high levels of follicle-stimulating hormone in serum; anti-Mullerian serum hormone levels below normal and more than three in vitro fertilization attempts. It is the method of multivariate mathematical analysis, considering all the most informative factors and variants of their expression, made it possible to create this prognostic model. The algorithm and mathematical model developed by the authors to predict the occurrence of this pathology, considering certain factors, have a high sensitivity and informativeness, which makes it possible to identify the risk groups of patients of reproductive age in the occurrence of this pathology in order to prevent and prescribe individual treatment in a timely manner.

Keywords: early climax, forecasting, mathematical model, risk groups, prevention.
\end{abstract}

\section{Introduction}

The great heritage of today is a significant increase in life expectancy, which, on the one hand, is linked to the development of modern medical technologies and, on the other, raises the already very high requirements for medical science and practice $[4,6,11,18]$. This is especially true for women's health, since it is women who live longer than men and more strongly resist age change and aging, trying to preserve not only beauty and youth but also reproductive function $[2,14,15,16]$.

As of $2016,46.7 \%$ of women in the structure of the 
female population of Ukraine are over 50 , while the average age of menopause in our country is 48.7 years $[3,4,5]$. According to numerous authors, as many as $40-80 \%$ of women of menopausal age have serious health disorders, which often leads to a decrease in labor productivity and social maladaptation, women in the age of their potentially greatest social activity, which with the transition to older age are deepening $[1,2,5,7]$.

Since age-related changes in both the reproductive system and the body as a whole begin precisely in the perimenopause, this requires the specialist's careful attention, since it is at this stage that long-term programs are needed to preserve the health of the female population $[4,5,9]$.

The aim is to develop an algorithm and a mathematical model for predicting the likelihood of early climax (EC) risk on the background of biological aging of the woman's body against the background of studying various factors with the further development of individualized prevention and treatment measures.

\section{Materials and methods}

In order to study the possibility of predicting the occurrence of EC on the background of biological aging of the woman's body, a retrospective analysis of the frequency of the studied factors in patients with EC compared with women with persistent menstrual function and timely onset of menopause was conducted. Retrospective studies were conducted using a specially designed questionnaire according to which 325 women aged $38-45$ years were surveyed. The retrospective study group consisted of 171 women aged 38-45 years, of whom 97 were with early menopause and 74 were healthy women; the control retrospective group consisted of 154 women of the same age, 72 of them with early menopause and 82 healthy women. The observation was conducted on the basis of the Department of Endocrine Gynecology, State institution institute of pediatrics obstetrics and gynecology named after academic Olena M. Lukyanova National Academy of Medical Sciences of Ukraine, Center for Innovative Medical Technologies.

As a mathematical model, we used the stepwise discriminant analysis method, which revealed the likelihood of difference between the groups of comparison by $F$ value of Fisher statistics, to develop a prediction algorithm and to perform mathematical modeling $[3,10]$. The magnitudes of the two discriminant functions $\left(f_{1}\right.$ and $\left.f_{2}\right)$ were determined, the first of which revealed the likelihood of the occurrence of EC, the second - denied such a possibility. Therefore, when $f_{1}>f_{2}$ predicted with varying degrees of probability the possibility of EC, when $f_{2}>f_{1}$ - rejected such a possibility. The probability level $(\mathrm{F} 1)$ of the predicted parameter was calculated by the formula: $F 1=1 /\left(e^{K 1}+e^{K 2}\right)$, where $K 1$ is the difference between the smaller and larger values of the discriminant functions, $K_{2}=0$. The magnitude of the prognosis was calculated by the magnitude of $\mathrm{F} 1$ : at
F1 $>0.75$ the probability of occurrence of the pathology was considered high, at F1=0.6-0.75 - medium, and at F1<0.6 low [10].

All digital data obtained were statistically processed using modern methods of variational statistics using Excel Microsoft Office 2015.

\section{Results}

12 out of 145 factors were identified by step-by-step discriminant analysis, which mostly influenced the occurrence of this pathology. The method of multivariate mathematical analysis considering all the most informative factors and variants of their expressiveness, made it possible to create this prognostic model. Among the factors most influential on the development of EC were: $X_{1}$ - onset of menopause in immediate relatives; $X_{2}$ - smoking; $X_{3}$ artificial abortions; $X_{4}$ - presence of extragenital pathology; $X_{5}$ - presence of stressful situations in everyday life, at work; $X_{6}$ - surgery on the uterus and appendages; $X_{7}$ - inadequate physical and mental activity; $X_{8}$ - obesity; $X_{9}$ - serum estradiol concentration; $X_{10}$ - the concentration of follicle-stimulating hormone in the serum; $X_{11}$ - the serum anti-Mullerian hormone concentration and $X_{12}$ - the use of assisted reproductive technologies, namely extracorporeal fertilization. With their subsequent indexing: $X_{1}$ (timely -1 , late - 2 , early - 3 ); $X_{2}$ (no smoking - 0 , smoking - 1 ); $X_{3}$ (none $-0,1-3$ abortions -1 , more than $3-2$ ); $X_{4}$ (none -0 , pathology of the respiratory system -1 , pathology of the kidneys and urinary system - 2 , cardiovascular diseases -3 , diseases of the nervous system - 4, autoimmune diseases - 5 , osteochondrosis of the cervical-thoracic spine -5 , several diseases - 6); $X_{5}$ (absent - 0, present - 1); $X_{6}$ (absent - 0 , present - 1); $X_{7}$ (absent - 0, present - 1 ); $X_{8}$ (no - 0, obesity 1); $X_{9}$ (norm - 1, above norm - 2, below norm - 3); $X_{10}$ (norm - 1, below norm - 2, above norm - 3); $X_{11}$ (norm - 1, above norm - 2, below norm - 3) and $X_{12}$ (absent - 0 , present - 1).

The discriminant features of the prediction of early menopause against the background of biological aging of a woman were as follows:

$f_{1}=-19.8+2.1 \times X_{1}+3.5 \times X_{2}+2.4 \times X_{3}+1.4 \times X_{4}-7.5 \times X_{5}$ $+2.7 \mathrm{xX}_{6}+3.5 \mathrm{xX}_{7}-2.9 \mathrm{xX}_{8}+1.3 \mathrm{xX}_{9}+2.6 \mathrm{xX}_{10}+4.4 \mathrm{xX}_{11}$ $+2.1 \times X_{12}$

$f_{2}=-18.3+1.3 \times X_{1}+2.9 x X_{2}+1.2 x X_{3}+2.1 \times X_{4}+5.6 x$ $X_{5}+0.3 \times X_{6}+0.8 x X_{7}+1.1 \times X_{8}+5.5 x X_{9}+3.1 \times X_{10}-7.1 \times X_{11}$ $+0.5 \times X_{12}$

де $f_{1}$ - discriminant function that determines the likelihood of this pathology occurrence, $f_{2}$ - denies this possibility, therefore the appointment $f_{1}>f_{2}$, predicted the possibility of early climax, and at $f_{2}>f_{1}$ - considered unlikely the possibility of this pathology occurrence. The values of the coefficients for the functions $f_{1}(-19.8)$ and $f_{2}(-18.3)$ were unchanged.

3 degrees of forecast probability are determined based on the curve of the frequency of early climax occurrence on the $\mathrm{FI}$ value. Moreover, at $\mathrm{FI}>0.8$ considered high probability of early climax development, at $\mathrm{Fl}=0.5-0.79$ - medium, and 
Table 1. Frequency of occurrence of $E C$ on the background of biological aging of a woman's body according to retrospective analysis.

\begin{tabular}{|c|c|c|c|c|c|c|}
\hline \multirow{3}{*}{ Probability } & \multirow{3}{*}{$\mathrm{FI}$} & \multirow{3}{*}{$\begin{array}{c}\text { Total } \\
\text { number }\end{array}$} & \multicolumn{4}{|c|}{ Experimental retrospective group } \\
\hline & & & \multicolumn{2}{|c|}{$\begin{array}{l}\text { with } \\
\text { manifestations of } \\
\text { EC }\end{array}$} & \multicolumn{2}{|c|}{$\begin{array}{c}\text { without } \\
\text { manifestations of } \\
\text { EC }\end{array}$} \\
\hline & & & absolute & $\%$ & absolute & $\%$ \\
\hline \multirow{5}{*}{ Low } & $<0,1$ & 13 & 0 & 0 & 13 & 100 \\
\hline & $0.1-0.19$ & 18 & 1 & 5.6 & 17 & 94.4 \\
\hline & $0.2-0.29$ & 15 & 6 & 40.0 & 9 & 60.0 \\
\hline & $0.3-0.39$ & 18 & 4 & 22.2 & 14 & 77.8 \\
\hline & $0.4-0.49$ & 13 & 5 & 38.5 & 8 & 61.5 \\
\hline \multicolumn{2}{|l|}{ Total } & 77 & 16 & 20.8 & 61 & 79.2 \\
\hline \multirow{3}{*}{ Average } & $0.5-0.59$ & 20 & 15 & 75.0 & 5 & 25.0 \\
\hline & $0.6-0.69$ & 15 & 11 & 73.3 & 4 & 26.7 \\
\hline & $0.7-0.79$ & 20 & 17 & 85.0 & 3 & 15.0 \\
\hline \multicolumn{2}{|l|}{ Total } & 55 & 43 & $78.2^{*}$ & 12 & $21.8^{*}$ \\
\hline \multirow{2}{*}{ High } & $0.8-0.9$ & 22 & 21 & 95.4 & 1 & 4.5 \\
\hline & $>0.9$ & 17 & 17 & 100 & 0 & 0 \\
\hline \multicolumn{2}{|l|}{ Total } & 39 & 38 & $97.4^{*}, \#$ & 1 & $2.6^{*}, \#$ \\
\hline
\end{tabular}

Notes: here and in the following tables ${ }^{*}$ - the difference is likely relative to the indicator in the low probability group $(p<0.001)$; \# the difference is likely relative to the mean in the group with average probability $(p<0.05)$

Table 2. The coincidence of the development of EC with the forecast in the experimental retrospective group.

\begin{tabular}{|c|c|c|c|}
\hline \multirow{2}{*}{ Performance forecast } & \multicolumn{2}{|c|}{ EC } & \multirow{2}{*}{ Total } \\
\cline { 2 - 3 } & developed & not developed & \\
\hline $\begin{array}{c}\text { Present } \\
\text { (high and medium probability) }\end{array}$ & 72 & 9 & 81 \\
\hline None (low probability) & 7 & 9 & 16 \\
\hline Total & 79 & 18 & 97 \\
\hline
\end{tabular}

at $\mathrm{Fl}<0.49$ - low. The difference between the incidence of early menopause in the low, medium, and high-risk groups (Table 1) was significant $(p<0.001)$.

High sensitivity of the developed algorithm for the prediction of the occurrence of EC in the experimental retrospective sample, which was $90.7 \%$, that is out of 97 women with early climax in 88 , was found. At the same time, $72(88.9 \%)$ of its occurrence was predicted with high or medium degree of probability $(\mathrm{Cl} 2.99-19.21, \mathrm{p}<0.05$, Table 2).

Moreover, the prediction accuracy for the high-risk group of early menopause was $97.4 \%$, the average one was $78.2 \%$, and the overall accuracy of the system was $86.2 \%$ - out of 94 women, who were projected to develop early menopause with high or medium probability, it was actually observed in 81 For the group with low risk of developing EC, the accuracy of the prognosis was $92.2 \%$, that is, out of 77 patients who did not predict the occurrence of EC in 71 there were no manifestations of this disease. That is, the expected results coincided with the real ones of this forecast model amounted to $79.2 \%$.

To check the reliability of the developed algorithm for predicting early menopause against the background of biological aging, we examined 154 women aged 38 to 45 years (control retrospective group), 72 of them - with manifestations of early menopause and 82 healthy women (Table 3).

When analyzing the indicators of the control retrospective group, we also found a high sensitivity of the prognostic system. Thus, of the 72 women who were diagnosed with early climax, $67(93.1 \%)$ predicted that it had a high or moderate probability. We also proved the high accuracy of the mathematical model in a control retrospective sample of 78 women who were expected to have an early climax with a high or medium probability, in 67 (85.9\%) we observed its occurrence. The coincidence of actual observed data with the theoretically expected data was in the high-risk group - $90.6 \%$, the average - $73.1 \%$, and in the group of patients where early menopause was not expected, the coincidence was recorded in $84.2 \%$ of cases.

In order to evaluate the prognostic value of the mathematical model we have developed, to confirm the established relationship of the obtained factors to the occurrence of EC with regard to the biological age of a woman, we have subsequently studied the trend of the disease. Therefore, in order to confirm the sensitivity of the prognostic systems developed, we tested their significance already in a prospective sample of 137 women aged 35 to 40 years with a high and medium risk of early menopause. Women have been under our observation for 2 to 5 years. During this observation period, symptoms of early

Table 3. Frequency of occurrence of EC on the background of biological aging of the female body in the control retrospective group.

\begin{tabular}{|c|c|c|c|c|c|c|}
\hline \multirow{3}{*}{ Probability } & \multirow{3}{*}{$\mathrm{FI}$} & \multirow{3}{*}{$\begin{array}{c}\text { Total } \\
\text { number }\end{array}$} & \multicolumn{4}{|c|}{ Experimental retrospective group } \\
\hline & & & \multicolumn{2}{|c|}{$\begin{array}{c}\text { with } \\
\text { manifestations of } \\
\text { EC }\end{array}$} & \multicolumn{2}{|c|}{$\begin{array}{c}\text { without } \\
\text { manifestations o } \\
\text { EC }\end{array}$} \\
\hline & & & absolute & $\%$ & absolute & $\%$ \\
\hline \multirow{5}{*}{ Low } & $<0,1$ & 13 & 0 & 0 & 13 & 100 \\
\hline & $0.1-0.19$ & 16 & 1 & 6.2 & 15 & 93.7 \\
\hline & $0.2-0.29$ & 21 & 3 & 14.3 & 18 & 85.7 \\
\hline & $0.3-0.39$ & 14 & 4 & 28.6 & 10 & 71.4 \\
\hline & $0.4-0.49$ & 12 & 4 & 33.3 & 8 & 66.7 \\
\hline \multicolumn{2}{|l|}{$\overline{\text { Total }}$} & 76 & 12 & 15.8 & 64 & 84.2 \\
\hline \multirow{3}{*}{ Average } & $0.5-0.59$ & 12 & 7 & 58.3 & 5 & 41.7 \\
\hline & $0.6-0.69$ & 14 & 9 & 64.3 & 5 & 35.7 \\
\hline & $0.7-0.79$ & 14 & 8 & 57.1 & 6 & 42.9 \\
\hline \multicolumn{2}{|l|}{ Total } & 40 & 24 & 60.0 & 16 & 40.0 \\
\hline \multirow{2}{*}{ High } & $0.8-0.9$ & 20 & 19 & 95.0 & 1 & 5.0 \\
\hline & $>0.9$ & 18 & 17 & 94.4 & 1 & 5.5 \\
\hline \multicolumn{2}{|l|}{ Total } & 38 & 36 & 94.7 & 2 & 5.3 \\
\hline
\end{tabular}


menopause occurred in 106 patients, ie the effectiveness of the prediction model in the prospective group was $77.4 \%$. Thus, long-term observations confirmed the predictive value of the developed mathematical model.

\section{Discussion}

Most scientists, today, distinguish the reproductive and biological age of each individual on the basis of obtaining the values of certain indicators that characterize the state of reproductive and general health $[13,17,19]$. In this case, age-related changes in the female body occur gradually, which gives modern medicine a chance to study and influence the processes of aging [5, 8, 12, 17, 19].

The results obtained prove the need to use prognostic programs to prevent the development of early menopause against the background of biological aging of a woman in order to develop individual preventive measures to preserve her health and improve her quality of life $[4,6,11,16]$. The use of prognostic models allows timely identification of women at risk of developing this pathology [4, 5]. J.T. Bromberger, H.M. Kravitz [5] and M. Birhaeuse, A.R. Genazzani [4] have shown that the study and consideration of risk factors for the occurrence of EC allows the development of preventive measures and prescribe individual treatment regimens in advance $[6,11,16]$.

The application of the algorithms and mathematical models of the prognosis of pathology in medical practice makes it possible to predict in advance not only the fact of the occurrence of this complication, but also to determine

\section{References}

[1] American College of Obstetricians and Gynecologists. (2014). ACOG Practice Bulletin No. 141: management of menopausal symptoms. Obstetr. Gynecol., 123(1), 202-216. doi: 10.1097/ 01.AOG.0000441353.20693.78

[2] Avis, N. E., Colvin, A., Bromberger, J. T., Hess, R., Matthews, K. A., Ory, M., \& Schocken, M. (2009). Change in health-related quality of life over the menopausal transition in a multiethnic cohort of middle-aged women: Study of Women's Health Across the Nation (SWAN). Menopause (New York, NY), 16(5), 860-869. doi: 10.1097/gme.0b013e3181a3cdaf

[3] Babich, P. N., Chubenko, A. V., \& Lapach, S. N. (2004). The use of modern statistical methods in the practice of clinical research. The second message. Chi-square application. Ukr. medical chronicle, 40(2), 138-144. ISSN: 1562-1146

[4] Birkhaeuser, M., \& Genazzani, A. R. (Eds.). (2018). PreMenopause, Menopause and Beyond: Volume 5: Frontiers in Gynecological Endocrinology. Springer. doi: 10.1007/978-3319-63540-8

[5] Bromberger, J. T., \& Kravitz, H. M. (2011). Mood and Menopause: Findings from the Study of Women's Health Across the Nation (SWAN) over ten years Obstet. Gynecol. Clin. North Am., 38(3), 609-625. doi: 10.1016/j.ogc.2011.05.011

[6] de Villiers, T., Tatarchuk, T. F., Avramenko, N. V., Bulavenko, O. V., Gabal', V. A., Burlaka, O. V., ... \& Golovach, I'.Yu. (2016). National consensus on the management of patients in menopause Reproductive endocrinology, (27), 8-25. https:// doi.org/10.18370/2309-4117.2016.27.8-25

[7] Dratva, J., Real, F. G., Schindler, C., Ackermann-Liebrich, U., the degree of probability of its occurrence, which is very important for the further identification of risk groups for the development of individualized prevention and treatment measures. Namely, the timely appointment of preventive measures and the development of individual treatment programs will improve the quality of life for each individual woman.

\section{Conclusions}

1. The identified risk factors for the development of early menopause on the background of biological aging of the body of the woman and developed an algorithm and mathematical model for the prediction of the occurrence of this pathology have high sensitivity and informativeness, which makes it possible to distinguish the risk groups of patients of reproductive age in the emergence of this pathology and the appointment of individual treatment regimens.

2. The most influential risk factors for the occurrence of EC on the background of biological aging of the woman's body were: early menopause in relatives, smoking, history of artificial abortions, the presence of extragenital pathology; presence of stressful situations in everyday life, at work; surgery on the uterus and appendages; inadequate physical and mental activity; adiposity; low serum estradiol concentrations; high levels of follicle-stimulating hormone in serum; serum anti-Mullerian hormone concentrations below normal and more than three attempts at extracorporeal fertilization.

Gerbase, M. W., Probst-Hensch, N. M., ... \& Morabia, A. (2009). Is age at menopause increasing across Europe? Results on age at menopause and determinants from two populationbased studies. Menopause, 16(2), 385-394. doi: 10.1097/ gme.0b013e31818aefef

[8] El Khoudary, S. R., Greendale, G., Crawford, S. L., Avis, N. E., Brooks, M. M., Thurston, R. C., ... \& Matthews, K. (2019). The menopause transition and women's health at midlife: a progress report from the Study of Women's Health Across the Nation (SWAN). Menopause (New York, NY), 26(10), 12131227. doi: $10.1097 / G M E .0000000000001424$

[9] ESHRE Capri Workshop Group. (2011). Perimenopausal risk factors and future health. Human reproduction update, 17(5), 706-717. doi: 10.1093/humupd/dmr020

[10] Glanz, S. (1999). Biomedical statistics. M.: Practice. ISBN 007-024268-2

[11] Kaminsky, V. V., Antipkin, Y. G., \& Tatarchuk, T. F. (2017). Maintaining the quality of life and social activity of women in the post-reproductive period. Reproductive endocrinology, (36), 9-12. https://doi.org/10.18370/2309-4117.2017.36.9-12

[12] Neal-Perry, G., Nejat, E., \& Dicken, C. (2010). The neuroendocrine physiology of female reproductive aging: an update. Maturitas, 67(1), 34-38. doi: 10.1016/ j.maturitas.2010.04.016

[13] Sebastiani, P., Thyagarajan, B., Sun, F., Schupf, N., Newman, A. B., Montano, M., \& Perls, T. T. (2017). Biomarker signatures of aging. Aging cell, 16(2), 329-338. doi: 10.1111/acel.12557

[14] Sowers, M. R., Zheng, H., McConnell, D., Nan, B., Harlow, S. 
D., \& Randolph Jr, J. F. (2008). Estradiol rates of change in relation to the final menstrual period in a population-based cohort of women. The Journal of Clinical Endocrinology \& Metabolism, 93(10), 3847-3852. doi: 10.1210/jc.2008-1056

[15] Tarlatzis, B., \& Bosdou, J. (2018). Oocyte Donation in Perimenopausal and Menopausal Women. In Pre-Menopause, Menopause and Beyond (pp. 95-101). Springer, Cham. doi: 10.1097/GME.0000000000000622

[16] Tatarchuk, T. F., \& Yefymenko, O. A. (2009). Principles of diagnostics, prevention and treatment of menopausal disorders. Journal of Ukrainian Medical Elite, 4(10), 24-29. ISSN: 1997-969X
[17] Tehrani, F. R., Shakeri, N., Solaymani-Dodaran, M., \& Azizi, F. (2011) Predicting age at menopause from serum antimullerian hormone concentration. Menopause, 18(7), 766-770. doi: 10.1097/gme.0b013e318205e2ac

[18] Totchiev, G. F., Kotikova, N. P., Semyatov, S. D., \& Toktar, L. R. (2012). Menopause. Modern aspects of forecasting. Bulletin of Peoples' Friendship University of Russia. Series: Medicine. Obstetrics and Gynecology, (5), 494-500. https://doi.org/ 10.18370/2309-4117.2012.5.494-9

[19] Xia, Y., \& Schneyer, A. L. (2009). The biology of activin: recent advances in structure, regulation and function. The Journal of endocrinology, 202(1), 1-12. doi: 10.1677/JOE-08-0549

\section{ПРОГНОЗУВАННЯ ВИНИКНЕННЯ РАННЬОГО КЛІМАКСУ З УРАХУВАННЯМ ПОКАЗНИКІВ РЕПРОДУКТИВНОГО ТА БІОЛОГІЧНОГО ВІКУ}

\section{Єфіменко О.О., Ретунська І.М., Мартиросова Т.О.}

Великим надбанням сьогодення є суттєве збільшення тривалості життя. Особливо це стосується питань жіночого здоров'я, так як саме жінки живуть довще, ніж чоловіки і більш завзято протистоять віковим змінам та старінню, намагаючись зберегти не тільки красу та молодість, а й репродуктивну функцію. Застосування в медичній практиці алгоритмів та математичних моделей прогнозу виникнення патології дає можливість завчасно спрогнозувати не лише факт виникнення даного ускладнення, а й визначити ступінь ймовірності його настання, що дуже важливо для подальшого виділення груп ризику з метою розробки індивідуалізованих заходів профрілактики та лікування. Саме вчасне призначення профрілактичних заходів та розробка індивідуальних програм лікування дозволить покращити якість життя кожної окремої жінки. Мета роботи - розробити алгоритм та математичну модель прогнозування ймовірності ризику розвитку раннього клімаксу (РК) на тлі біологічного старіння організму жінки та вивчення різних факторів з подальшою розробкою індивідуалізованих заходів профрілактики та лікування. 3 метою вивчення можливостей прогнозування виникнення РК на тлі біологічного старіння організму жінки було проведено ретроспективний аналіз частоти досліджуваних чинників у пацієнток з РК порівняно з жінками зі збереженою менструальною фрункцією та своєчасним настанням менопаузи. В якості математичної моделі використовували метод покрокового дискримінантного аналізу, який дозволив виявити вірогідність різниці між групами порівняння за величиною $F$ статистики Фішера, розробити алгоритм прогнозу і провести математичне моделювання. Методом покрокового дискримінантного аналізу визначено 12 із 145 чинників, що найбільщою мірою впливали на виникнення даної патології, серед яких було виявлено: рання менопауза у родичок, паління, штучні аборти в анамнезі (більще 3), наявність екстрагенітальної патології; наявність стресових ситуацій в побуті й на роботі; хірургічні втручання на матці і додатках; неадекватні фрізичні та розумові навантаження; ожиріння; знижена концентрація естрадіолу в сироватці крові; висока концентрація фолікулостимулюючого гормону в сироватиі крові; знижена концентрація Антимюлерового гормону в сироватці крові та більше трьох спроб екстракорпорального запліднення. Метод багатофракторного математичного аналізу з урахуванням усіх найбільш інформативних факторів та варіантів їх вираженості дав можливість створення даної прогностичної моделі. Розроблений алгоритм і математична модель з прогнозування виникнення даної патології з урахуванням визначених факторів мають високу чутливість та інформативність, що дає можливість виділити групи ризику пацієнток репродуктивного віку щодо виникнення даної патології у них з метою своєчасної профрілактики та призначення індивідуальних схем лікування.

Ключові слова: ранній клімакс, прогнозування, математична модель, групи ризику, просрілактика.

\section{ПРОГНОЗИРОВАНИЕ ВОЗНИКНОВЕНИЯ РАННЕГО КЛИМАКСА С УЧЕТОМ ПОКАЗАТЕЛЕЙ РЕПРОДУКТИВНОГО И БИОЛОГИЧЕСКОГО ВОЗРАСТА}

Ефименко О.А., Ретунська И.Н., Мартиросова Т.А.

Большим достоянием современности является существенное увеличение продолжительности жизни. Особенно это касается вопросов женского здоровья, так как женщины живут дольше мужчин и более упорно противостоят возрастным изменениям и старению, пытаясь сохранить не только красоту и молодость, но и репродуктивную функцию. Применение в медицинской практике алгоритмов и математических моделей прогноза возникновения патологии дает возможность заблаговременно спрогнозировать не только факт возникновения данного осложнения, но и определить степень вероятности его наступления, что очень важно для последующего выделения групп риска с целью разработки индивидуализированных мер профрилактики и лечения. А именно своевременное назначение профилактических мероприятий и разработка индивидуальных программ лечения позволит улучшить качество жизни каждой женщины. Цель работы разработать алгоритм и математическую модель прогнозирования вероятности риска развития раннего климакса (РК) на фоне биологического старения организма женщины путем изучения различных фракторов с последующей разработкой индивидуализированных мер профилактики и лечения. С иелью изучения возможностей прогнозирования возникновения $Р К$ на фоне биологического старения организма женщины был проведен ретроспективный анализ частоты исследуемых факторов у пациенток с РК в сравнении с женщинами с сохраненной менструальной фуннцией и своевременным наступлением менопаузы. В качестве математической модели использовали метод пошагового дискриминантного анализа, который позволил выявить вероятность разницы между группами сравнения по величине $\mathrm{F}$ статистики Фишера, разработать алгоритм прогноза и провести математическое моделирование. Методом пошагового дискриминантного анализа определены 12 из 145 факторов, которые в наибольшей степени влияли на возникновение данной патологии: ранняя менопауза у родственнии, курение, искусственные аборты в анамнезе (более 3), наличие экстрагенитальной патологии; 
наличие стрессовых ситуаций в быту и на работе; хирургические вмешательства на матке и придатках; неадекватные физические и умственные нагрузки; ожирение; сниженная концентрация эстрадиола в сыворотке крови; высокая концентрация фолликулостимулирующего гормона в сыворотке крови, сниженная концентрация Антимюллерового гормона в сыворотке крови и более трех попыток экстракорпорального оплодотворения. Метод многофакторного математического анализа с учетом всех наиболее информативных факторов и вариантов их выраженности дал возможность создания данной прогностической модели. Разработанный авторами алгоритм и математическая модель по прогнозированию возникновения данной патологии с учетом определенных факторов имеют высокую чувствительность и информативность, что дает возможность выделить группы риска пациенток репродуктивного возраста относительно возникновения у них данной патологии с целью своевременной профилактики и назначения индивидуальных схем лечения.

Ключевые слова: ранний климакс, прогнозирование, математическая модель, группы риска, профилактика. 